\section{Is There a Relationship Between Periodontal Disease and Causes of Death? A Cross Sectional Study}

\author{
Zuhair S. Natto ${ }^{1,2}$, Majdi Aladmawy', Mohammed Alasqah ${ }^{1}$, Athena Papas ${ }^{3}$
}

\author{
'Department of Periodontology, \\ Tufts University School of Dental \\ Medicine, Boston, MA, USA \\ ${ }^{2}$ Department of Dental Public Health, \\ King Abdualziz University, School \\ of Dentistry , Jeddah ,Saudi Arabia \\ 3Division of Dental Public Health \\ Research and Oral Medicine, \\ Tufts University School of Dental \\ Medicine, Boston, MA, USA
}

Correspondence: Dr. Zuhair Natto, One Kneeland Street, Boston, MA 02111, USA. Tel: +1-909-702-4119. e-mail: zuhair.natto@tufts.edu

Key Words: periodontal disease, mortality, diabetes, cardiovascular disease, elderly.

\section{Introduction}

Periodontal diseases contains multiple infectious pathogens that can induce inflammation to the surrounding soft or/and hard tissues, a bacterial niche combines mixed gram positive (early colonizers) and negative (late colonizers) bacteria. When the bacterial infection is combined with a susceptible host the periodontal breakdown is initiated (1).

Factors that induce inflammation include the bacterial biofilm, bacterial by products, e.g. lipopolysaccharides, and host immune interactions with the bacterial products. The host immune cell receptors (pattern recognition receptors, PRR) can recognize the presence of bacterial pathogens by pathogen-associated molecular patterns (PAMP), which bind to the host receptors. When this interaction between PAMPs and PRRs occurs, immune cells produce pro-inflammatory cytokines to the site associated with the presence of bacteria (2). The host immune system is mainly activated for a protective function, but sometimescollateral damage to non-pathologic cells does occur. The severity of the periodontal breakdown caused by inflammation depends on the balance between the bacterial virulence and the host immune reaction (2).

The host and the microbial challenge interaction can be further influenced by a variety of systemic conditions one of this conditions is cardiovascular disease (CVD). A previous study indicated an association between periodontitis and CVD, but the observed association was modest. People with periodontitis were at a greater risk of coronary heart disease, when compared with healthy controls. The number of remaining teeth was reported to have an association with coronary heart disease. It was stated that subjects with less than 10 remaining teeth had a high risk of coronary heart disease when compared to subjects that had more remaining teeth.

A cross-sectional study for patients with periodontitis found that coronary heart disease had a high prevalence with periodontitis patients when compared to healthy subjects (4). Periodontitis can be considered as a risk factor for coronary heart disease, but prospective studies are needed to determine if there a causation between both diseases.

Diabetes mellitus should be considered as a systemic condition that interferes with relationship between the virulent microbial invasion and the host response. Diabetes mellitus is a metabolic disorder having a reduced function, or lack of function from the beta cells in the islets of Langerhans present in the pancreas, this leads to high concentrations of blood glucose levels in the blood serum and presence of sugar in urine (5). Diabetes is one of the prevalent diseases among the metabolic disorders, 
the incidence of diabetes around the world continues to increase (6). As people get older their susceptibility to diabetes increases, which is a similar finding for periodontitis and age (7).

Some reports termed periodontitis as the "Sixth Complication" of diabetes (8). There is no conscience relating diabetes to the initiation of periodontitis. Different opinions debating the correlation between diabetes and periodontitis are still ongoing.

The earliest report of an association between periodontitis and different causes of mortality was done by DeStefano et al. (9) After 14 years of follow-up in the NHANES 1 study, they reported that subjects with periodontitis had a $50 \%$ increase in mortality risk (9).

The aim of the current study was to evaluate if there is any relationship between periodontal disease and major causes of death such as hypertension and diabetes mellitus in the studies population.

\section{Material and Methods}

This study recruited volunteers from the Boston and its is surrounding areas (57\% from Tufts Geriatric Outreach program and 43\% from Tufts dental clinics). The Tufts people.

Selection criteria for enrollment in the study included being a local Boston area resident, presence of six or more teeth, being free from terminal illness, endocrine disease that would affect nutrition; recent unexplained weight loss; and active alcoholism, and being willing and able to complete a 3-day food diary in a predetermined manner. Each participant signed a consent form agreeing to participate in the study. The Human Investigation Review Committee of Tufts University approved conduction of the study

Clinical oral examinations were done at Tufts University School of Dental Medicine by a single examiner using artificial light, explorer, mirror and air syringe. The teeth were dried before examination to assess the dental decay. The coronal and root caries and periodontal measurements were made on all subjects according to the diagnostic criteria used in the US adult survey. Third molars were excluded from examination. Training and calibration sessions to standardize caries and periodontal measurements were held semi-annually. Questionnaires on health knowledge, attitudes and behavior, and general and medication history were also administered. Causes of death abstracted from death certificate.

It was expected to have 90\% power based on: OR of 2.14 for CVD group compared with the group still living, a sample size of 284 , and $\alpha=0.05$. The sample size was calculated using $\mathrm{G}^{*}$ power software, version 3.1 (University Kiel, Germany).

Descriptive statistics were expressed as mean \pm SD or $\mathrm{N}(\%)$. The values of each variable were compared between groups, according to the cause of death (cardiovascular, diabetes, unknown cause of death) or still living. The Shapiro-Wilk test was used to evaluate normality. Analysis of variance and chi-square were applied.

The odds ratios of developing recession (continuous or categorical) or pocket depth (continuous or categorical) adjusting for significant variables in reduced model or all variables in full model, comparing CVD, diabetic or unknown cause of death to still living group, were estimated by the use of logistic regression. Analyses were performed using SAS software v. 9.3 (SAS Institute, Cary, NC, USA).

\section{Results}

This study compared the demographics and different causes of death (Table 1). The demographics of the study population indicated that, most of the sample was female (except for diabetes mellitus), white, married, with 13 years of education, and 83 years old on average. They had deeper CAL $(\geq 3 \mathrm{~mm})$ and shallower pocket depth $(<3$ $\mathrm{mm}$ ). CAL (continuous or dichotomous) and marital status attained statistical significance $(p<0.05)$ in contingency table analysis (chi-square test for independent samples).

\section{Clinical Attachment Level (CAL) and Cause of Death}

In a logistic regression model with cause of death (CVD, diabetes mellitus, or died out of state) versus still living group as the outcome variable and with marital status and CAL (continuous in the first model and categorical in the second one) as covariates, we found that individuals with increased CAL were 2.16 times more likely (OR 2.16, 95\% $\mathrm{Cl} 1.47-3.17)$ to have mortality due to CVD when compared to individuals that had normal CAL. This effect persisted even after control for age, marital status, gender, race, and years of education. We have the same results with dichotomous CAL, which was 2.7 times for marital status adjusted (OR 2.70, 95\% 1.32-5.53) and 3.25 times for multivariable adjusted model (OR 3.25, 95\%1.44-7.30). CAL (continuous or dichotomous) was much higher among those who died due to diabetes mellitus or out of state. However, these results were not statistical significant.

\section{Pocket Depth and Cause of Death}

In further analyses of logistic regression model (Table 3) with the same outcome variable with marital status and pocket depth (PD) (continuous in the first model and categorical in the second one) as covariates, we found that pocket depth (continuous or dichotomous) was much 
higher among those who died due to CVD, diabetes mellitus or out of state compared with still living. However, these results were not statistically significant.

\section{Discussion}

The main finding of the present study was that 83-year-old individuals showed an association between increased CAL and CVD morbidity by 2.16 times compared with individuals with CVD without CAL and are still alive, when adjusted for age, marital status, gender, race, year of education. The same findings were present for diabetic patients but the statistical analysis showed that it was not significant, probably due to the small sample size of diabetic patients. Probing depth showed results that were higher

Table 1. Descriptive statistics of the study sample

\begin{tabular}{|c|c|c|c|c|c|}
\hline Variable & $\begin{array}{l}\text { CVD mortality } \\
\quad N=60\end{array}$ & $\begin{array}{c}\text { Diabetes } \\
\text { mortality } \mathrm{N}=50\end{array}$ & $\begin{array}{l}\text { Out of the state } \\
\text { mortality } N=26\end{array}$ & $\begin{array}{l}\text { Individuals that } \\
\text { are alive } N=148\end{array}$ & $p$ value \\
\hline Age $($ mean $\pm S D)$ & $82.90 \pm 10.74$ & $81.99 \pm 7.54$ & $85.14 \pm 7.78$ & $82.64 \pm 14.70$ & 0.758 \\
\hline \multicolumn{6}{|l|}{ Gender, $n(\%)$} \\
\hline Male & $27(47.4)$ & $28(57.1)$ & $12(46.2)$ & $54(38.9)$ & \multirow[t]{2}{*}{0.159} \\
\hline Female & $32(52.6)$ & $21(42.9)$ & $14(53.8)$ & $85(61.1)$ & \\
\hline \multicolumn{6}{|l|}{ Race, $n(\%)$} \\
\hline White & 48(90.6) & 43(87.8) & $26(100)$ & $123(89.8)$ & \multirow[t]{2}{*}{0.334} \\
\hline African American & $5(9.4)$ & $6(12.2)$ & $0(0.0)$ & $14(10.2)$ & \\
\hline \multicolumn{6}{|l|}{ Marital status, $n(\%)$} \\
\hline Single & $9(15.8)$ & $6(12.2)$ & $4(15.4)$ & $39(28.5)$ & \multirow[t]{3}{*}{$0.015^{*}$} \\
\hline Married & $28(49.1)$ & $25(51.1)$ & $12(46.2)$ & $74(54.0)$ & \\
\hline Others $^{* *}$ & $20(35.1)$ & 18(36.7) & 10(38.4) & $24(17.5)$ & \\
\hline \multicolumn{6}{|c|}{ Clinical attachment level (CAL) (mean \pm SD) } \\
\hline Buccal & $3.76 \pm 1.29$ & $3.50 \pm 1.21$ & $3.35 \pm 0.88$ & $3.20 \pm 0.95$ & $0.007^{*}$ \\
\hline lingual & $3.52 \pm 1.07$ & $3.30 \pm 1.17$ & $3.03 \pm 0.73$ & $2.92 \pm 0.91$ & $0.001^{*}$ \\
\hline Distal & $3.88 \pm 1.04$ & $3.67 \pm 1.06$ & $3.54 \pm 0.82$ & $3.32 \pm 0.97$ & $0.002^{*}$ \\
\hline Mesial & $3.87 \pm 1.08$ & $3.50 \pm 0.81$ & $3.50 \pm 0.73$ & $3.32 \pm 0.83$ & $0.001^{*}$ \\
\hline Total & $3.79 \pm 1.07$ & $3.50 \pm 0.85$ & $3.35 \pm 0.72$ & $3.19 \pm 0.82$ & $0.000^{*}$ \\
\hline \multicolumn{6}{|c|}{ Clinical attachment level (CAL) n(\%) } \\
\hline$\geq 3 \mathrm{~mm}$ & $45(75.0)$ & $31(62.0)$ & $17(65.4)$ & $79(53.4)$ & \multirow[t]{2}{*}{$0.033^{*}$} \\
\hline$<3 \mathrm{~mm}$ & $15(25.0)$ & $19(38.0)$ & $9(34.6)$ & $69(46.6)$ & \\
\hline \multicolumn{6}{|l|}{ Pocket depth (mean \pm SD) } \\
\hline Buccal & $1.63 \pm 0.36$ & $1.60 \pm 0.55$ & $1.50 \pm 0.33$ & $1.59 \pm 0.38$ & 0.604 \\
\hline Lingual & $1.77 \pm 0.54$ & $2.26 \pm 0.57$ & $1.68 \pm 0.40$ & $1.73 \pm 0.45$ & 0.387 \\
\hline Distal & $2.41 \pm 0.58$ & $2.28 \pm 0.64$ & $2.38 \pm 0.63$ & $2.34 \pm 0.58$ & 0.608 \\
\hline Mesial & $2.41 \pm 0.56$ & $1.85 \pm 0.48$ & $2.29 \pm 0.49$ & $2.41 \pm 0.59$ & 0.466 \\
\hline Total & $2.06 \pm 0.42$ & $2.01 \pm 0.45$ & $1.96 \pm 0.42$ & $2.02 \pm 0.43$ & 0.758 \\
\hline \multicolumn{6}{|l|}{ Pocket depth (mean \pm SD) } \\
\hline$\geq 3 \mathrm{~mm}$ & $1(1.7)$ & $1(2.0)$ & $1(3.9)$ & $6(4.1)$ & \multirow[t]{2}{*}{0.802} \\
\hline$<3 \mathrm{~mm}$ & 59(98.3) & 49(98.0) & $25(96.1)$ & 142(95.9) & \\
\hline Year of education $($ mean $\pm S D)$ & $12.95 \pm 2.74$ & $12.90 \pm 2.75$ & $13.80 \pm 2.60$ & $13.68 \pm 14.70$ & 0.104 \\
\hline
\end{tabular}

${ }^{*} p$ value $<0.05$. $p$ value obtained from either analysis of variance (ANOVA) for continuous variables, and chi-square for categorical variables. ${ }^{* *}$ other includes: divorced and widow. 
for individuals that had mortality with CVD or diabetes in comparison with patients that are still alive, but as mentioned it was not statistically significant.

Death was the final endpoint, causes of death were taken from the death certificate. The classification of the different categories was made before obtaining information on the patients. Population sample had both males and females (whites and African Americans). The analysis was adjusted for a wide range of relevant factors; however, we cannot exclude residual confounding factors as a possible explanation for the association observed in this study.

This study is unique in that it looked into the relationship between different periodontal parameters and the cause of death for diabetic and CVD patients. Strippoli et al (10), reported the association between periodontitis (in patients on hemodialysis), and mortality as an outcome, they found, that periodontitis might be associated with mortality in dialysis patients. The reviewed for well-designed, larger studies to look into the association between oral health and mortality (10), which is in agreement with the results of the present study.
Reports of an association between periodontitis and mortality was investigated by Linden et al (11) in a prospective study having a group of senior West European men from Belfast, Northern Ireland. During a 9-year follow up period that out of the 152 patients that died, 37 of them had CAL less than $1.8 \mathrm{~mm}$ while 73 had CAL of more than $2.6 \mathrm{~mm}$, they concluded that the group with severe loss of periodontal attachment were at an increased risk of death compared with individuals with lower loss of periodontal attachment (11).

A prospective study in China reported an association between periodontitis and CVD (12). However, they used PD as the main variable and found that there is an association between PD and CVD and all-cause mortality in men with ages between 30-64 years. Another observation found, was subjects that were older than 64 years did not show statistical significance between periodontitis and CVD (12).

Periodontitis, which affects tooth structures if not treated, would ultimately lead to tooth loss and a decrease in health quality due to inadequate chewing of food (13). Aida et al. (14) evaluated the oral health in old Japanese

\begin{tabular}{|c|c|c|c|}
\hline Variable & $\begin{array}{l}\text { OR }(95 \% \mathrm{Cl}) \mathrm{CVD} \text { mortality vs. } \\
\text { individuals that are still living }\end{array}$ & $\begin{array}{l}\text { OR }(95 \% \mathrm{Cl}) \mathrm{DM} \text { mortality vs. } \\
\text { individuals that are still living }\end{array}$ & $\begin{array}{l}\text { OR }(95 \% \mathrm{Cl}) \text { Out of state mortality } \\
\text { vs. individuals that are still living }\end{array}$ \\
\hline \multicolumn{4}{|l|}{ Marital status } \\
\hline Single & 1 & 1 & 1 \\
\hline Married & $2.74(0.88-8.51)$ & $2.24(0.74-6.76)$ & $1.40(0.39-5.04)$ \\
\hline Others ${ }^{* *}$ & $5.77(1.64-20.32)^{*}$ & $5.56(1.61-19.19)^{*}$ & $3.60(0.88-14.77)$ \\
\hline Age & $0.99(0.95-1.02)$ & $0.98(0.95-1.01)$ & $1.00(0.96-1.05)$ \\
\hline \multicolumn{4}{|l|}{ Gender } \\
\hline Male & 1 & 1 & 1 \\
\hline Female & $0.73(0.34-1.56)$ & $0.44(0.20-0.98)^{*}$ & $0.63(0.25-1.59)$ \\
\hline \multicolumn{4}{|l|}{ Race } \\
\hline White & 1 & 1 & - \\
\hline African American & $0.73(0.20-2.68)$ & $1.23(0.38-3.98)$ & - \\
\hline Year of education & $0.94(0.80-1.10)$ & $0.91(0.77-1.07)$ & $1.02(0.83-1.25)$ \\
\hline \multicolumn{4}{|l|}{ CAL } \\
\hline \multicolumn{4}{|l|}{ Model 1} \\
\hline Total & $2.03(1.35-3.03)^{*}$ & $1.46(0.93-2.31)$ & $1.24(0.70-2.21)$ \\
\hline \multicolumn{4}{|l|}{ Model 2} \\
\hline$\geq 3 \mathrm{~mm}$ & $3.25(1.44-7.30)^{*}$ & $1.15(0.54-2.46)$ & $1.37(0.54-3.52)$ \\
\hline$<3 \mathrm{~mm}$ & 1 & 1 & 1 \\
\hline
\end{tabular}

$\mathrm{OR}=$ odds ratio; $\mathrm{Cl}=$ confidence interval. $§$ Adjusted for Age, Marital status, gender, race, year of education. In addition to the main exposure which is clinical attachment level as a continuous or categorical. ${ }^{*} p$ value $<0.05$. ${ }^{* *}$ other includes: divorced and widow. 
patients and mortality relationship, and found that CVD and respiratory disease mortality were significant (14), which agrees with the current study.

Thorstensson et al. (15) studied oral health relation to survival in old population of $>80$ year-old Swedish patients, which corresponds to the same age group in our study. The authors reported that oral health was significantly associated with subsequent survival in a sample of 80 -yearold individuals (15).

Oliveira et al. (16) examined a population younger than 50 years of age in Scotland and reported on the oral hygiene maintenance association with risk of CVD. The authors found that inadequate oral hygiene was associated with a high risk of developing CVD, and mild inflammation (16).

There are some limitations associated with our study; this is a convenience sample and the sample distribution is not representative for the United States population, the sample is not chosen at random, the inherent bias in convenience sampling means that inability to generalize our results to the US population. Population size is small for such epidemiological studies. The present research was cross-sectional study, this gives a limitation on applying causality between the variables being tested. We plan to report on a longitudinal study having a larger sample size representing the area in the future.

Literature has shown several studies that support our results in that higher mortality rates were associated with subjects that have CAL with CVD when compared with periodontally healthy patients with CVD $(17,18)$. Our findings indicate that treatment should be given to the elderly population to prevent attachment loss around the teeth, as it is observed to increase mortality rates among individuals with CVD. Attachment loss is associated with bacterial deposition on both hard and soft tissues surrounding the tooth. Bacterial virulence can be controlled with regular maintenance visits to the dentist or hygienist. Patient should be educated on the importance of maintaining their $C A L$, as it can be of valuable information for them to increase their quality and longevity in life. There should be further research in this topic to identify how CVD is associated with periodontitis.

People that had mortality due to CVD have a higher CAL

Table 3. Association of pocket depth (PD, continuous in model 1 and categorical in model 2) in several systemic diseases compared with individuals that have the same disease but are still living using multivariable adjusted models §

\begin{tabular}{|c|c|c|c|}
\hline Variable & $\begin{array}{l}\text { OR }(95 \% \mathrm{Cl}) \mathrm{CVD} \text { mortality vs. } \\
\text { individuals that are still living }\end{array}$ & $\begin{array}{l}\text { OR }(95 \% \mathrm{Cl} \text { DM mortality vs. } \\
\text { individuals that are still living }\end{array}$ & $\begin{array}{l}\text { OR }(95 \% \mathrm{Cl}) \text { Out of state mortality } \\
\text { vs. individuals that are still living }\end{array}$ \\
\hline \multicolumn{4}{|l|}{ Marital status } \\
\hline Single & 1 & 1 & 1 \\
\hline Married & $1.98(0.72-5.43)$ & $2.29(0.79-6.62)$ & $1.33(0.37-4.78)$ \\
\hline Others ${ }^{* *}$ & $4.83(1.56-14.94)^{*}$ & $6.69(2.00-22.30)^{*}$ & 3.66(0.90-14.93) \\
\hline Age & $0.99(0.96-1.02)$ & $0.98(0.95-1.01)$ & $1.01(0.97-1.05)$ \\
\hline \multicolumn{4}{|l|}{ Gender } \\
\hline Male & 1 & 1 & 1 \\
\hline Female & $0.58(0.28-1.18)$ & $0.36(0.17-0.76)^{*}$ & $0.62(0.25-1.55)$ \\
\hline \multicolumn{4}{|l|}{ Race } \\
\hline White & 1 & 1 & - \\
\hline African American & $0.80(0.24-2.68)$ & $1.39(0.43-4.50)$ & - \\
\hline Year of education & $0.89(0.77-1.03)$ & $0.88(0.76-1.02)$ & $1.01(0.83-1.24)$ \\
\hline \multicolumn{4}{|l|}{ PD } \\
\hline \multicolumn{4}{|l|}{ Model 1} \\
\hline Total & $1.15(0.51-2.59)$ & $0.81(0.36-1.82)$ & $1.11(0.35-3.58)$ \\
\hline \multicolumn{4}{|l|}{ Model 2} \\
\hline$\geq 3 \mathrm{~mm}$ & - & $0.36(0.04-3.24)$ & $1.79(0.17-18.97)$ \\
\hline$<3 \mathrm{~mm}$ & - & 1 & 1 \\
\hline
\end{tabular}

OR, odds ratio; $\mathrm{Cl}$, confidence interval. § Adjusted for Age, Marital status, gender, race, year of education. In addition to the main exposure which is clinical attachment level as a continuous or categorical. ${ }^{*} \mathrm{p}$ value $<0.05 .{ }^{* *}$ other includes: divorced and widow. 
loss compared with people who are still living with CVD. $P D$, in contrast, did not change between the two groups. In addition, subjects with Diabetes mellitus and people that died out of Massachusetts had the same pattern of attachment lose but the results were not significant.

\section{Resumo}

O objetivo deste estudo foi avaliar se existe relação entre doença periodontal e fatores de mortalidade como, por ex., doenças cardiovasculares e diabetes melitus, numa amostra de pessoas idosas. Um único examinador fez avaliação dentária em 284 pacientes. As avaliações periodontais foram feitas com sonda manual UNC-15 para medir profundidade da bolsa e nivel de inserção clínica em 6 pontos. As causas dos óbitos foram obtidas das certidões. Para análise estatística utilizou-se ANOVA, teste do qui-quadrado e análise de regressão logistica multivariada. Os dados demográficos indicaram que a maioria era constituida de mulheres (exceto para diabetes melitus), leucodermas, casadas, completaram 13 anos de escolaridade e média de 83 anos de idade. 0 nível de inserção clínica (contínuo ou dicotomizado) e estado civil tiveram significância estatistica $(p<0,05)$ na análise das tabelas de contingência (qui-quadrado para independentes). 0 nivel de inserção clínica foi 2,16 vezes mais provável causa de óbito $(\mathrm{OR}=2,16 ; 95 \% \mathrm{Cl} 1,47-3,17)$ por doença cardiovascular que o grupo dos sobreviventes e este efeito persistiu mesmo depois de controlados idade, estado civil, sexo, raça e anos de escolaridade $(\mathrm{OR}=2,03$, $95 \% \mathrm{Cl} 1.35-3.03$ ). 0 nivel de inserção clínica (contínuo ou dicotomizado) foi muito maior entre os que morreram por diabetes melitus ou fora do estado de Massachusetts, mas estes resultados não foram estatisticamente significantes. 0 mesmo ocorreu com a profundidade da bolsa gengival (contínua ou dicotomizada), mas estes resultados também não foram estatisticamente significantes. Aparentemente a inserção clínica é mais afetada pelas doenças crônicas em comparação com a profundidade da bolsa. Entre estas doenças, as cardiovasculares têm efeito mais forte.

\section{References}

1. Offenbacher S. Periodontal diseases: pathogenesis. Ann Periodontol 1996;1:821-878

2. Madianos PN, Bobetsis YA, Kinane DF. Generation of inflammatory stimuli: how bacteria set up inflammatory responses in the gingiva. J Clin Periodontol 2005;32:57-71.

3. Scannapieco FA, Bush RB, Paju S. Associations between periodontal disease and risk for atherosclerosis, cardiovascular disease, and stroke. A systematic review. Ann Periodontol 2003;8:38-53.

4. Bahekar AA, Singh S, Saha S, Molnar J, Arora R. The prevalence and incidence of coronary heart disease is significantly increased in periodontitis: a meta-analysis. Am Heart J 2007;154:830-7.
5. Macleod J. English language book society. 14th ed. Philadelphia (US): Churchill Livingstone; 1984. Davidson's principles and practice of medicine.

6. Shah SN, Tripathy BB. API textbook of medicine. In: Sainani GS, Anand MP, Billimoria AR, Chugh KS, Joshi VR, Mehta PJ. 15th ed. Bombay: Association of Physicians of India; 1994.

7. Schluger $\mathrm{S}$, Yuodelis R, Page RC, Johnson RH. Periodontal diseases: Basic phenomena, clinical management and occlusal and restorative interrelationships. 2nd ed. Philadelphia, London: Lea and Febiger; 1990

8. Grossi SG, Skrepcinski FB, DeCaro T, Zambon JJ, Cummins D, Genco RJ. Response to periodontal therapy in diabetics and smokers. J Periodontol 1996;67:1094-1102.

9. DeStefano F, Anda RF, Kahn HS, Williamson DF, Russell CM. Dental disease and risk of coronary heart disease and mortality. BMJ 1993;306:688-691.

10. Strippoli GF, Palmer SC, Ruospo M, Natale P, Saglimbene V, Craig JC, et al. Oral disease in adults treated with hemodialysis: prevalence, predictors, and association with mortality and adverse cardiovascular events: the rationale and design of the ORAL Diseases in hemodialysis (ORAL-D) study, a prospective, multinational, longitudinal, observational, cohort study. BMC Nephrol 2013;14:90.

11. Linden GJ, Linden K, Yarnell J, Evans A, Kee F, Patterson CC. All-cause mortality and periodontitis in 60-70-year-old men: a prospective cohort study. J Clin Periodontol $2012 ; 39: 940-946$.

12. $\mathrm{X} \cup \mathrm{F}, \mathrm{Lu} \mathrm{B}$. Prospective association of periodontal disease with cardiovascular and all-cause mortality: NHANES III follow-up study. Atherosclerosis 2011; 218:536-542.

13. Natto ZS, Aladmawy M, Alasqah M, Papas A. Factors contributing to tooth loss among the elderly: A cross sectional study. Singapore Dent J 2014;35:17-22.

14. Aida J, Kondo $K$, Yamamoto T, Hirai H, Nakade M, Osaka K. Oral health and cancer, cardiovascular, and respiratory mortality of Japanese. J Dent Res. 2011;90:1129-1135

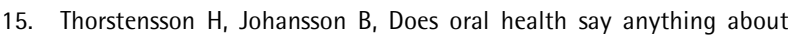
survival in later life? Findings in a Swedish cohort of $80+$ years at baseline. Community Dentistry and Oral Epidemiology 2009;37:325332.

16. Oliveira $C$, Watt $R$, Hamer M. Toothbrushing, inflammation, and risk of cardiovascular disease: results from Scottish Health Survey. BMJ 2010;27;340:c2451.

17. Schwahn C, Polzer I, Haring R, Dörr M, Wallaschofski $H$, Kocher $T$, et al.. Missing, unreplaced teeth and risk of all-cause and cardiovascular mortality. Int J Cardiol. 2013;167:1430-1437.

18. Heitmann BL, Gamborg M. Remaining teeth, cardiovascular morbidity and death among adult Danes. Prev Med 2008;47:156-160.

Received June 6, 2014 Accepted December 13, 2014 